\title{
The larva and prepupa of Eupareophora exarmata (Thomson, 1871) (Hymenoptera, Tenthredinidae)
}

\author{
Andrew David Liston $¥$, Marko Prous ${ }^{\ddagger}$, , Josef Bückerl \\ ‡ Senckenberg Deutsches Entomologisches Institut, Müncheberg, Germany \\ $\S$ Department of Zoology, Institute of Ecology and Earth Sciences, University of Tartu, Tartu, Estonia \\ | In der Geweke 40, Hagen, Germany
}

Corresponding author: Andrew David Liston (andrew.liston@senckenberg.de)

Academic editor: Michael Kuhlmann

Received: 10 Nov 2015 | Accepted: 24 Nov 2015 | Published: 25 Nov 2015

Citation: Liston A, Prous M, Bücker J (2015) The larva and prepupa of Eupareophora exarmata (Thomson,

1871) (Hymenoptera, Tenthredinidae). Biodiversity Data Journal 3: e7147. doi: 10.3897/BDJ.3.e7147

\section{Abstract \\ Background}

Of the two known Eupareophora species, more is known about the larva and bionomics of the Nearctic E. parca, than the rarely recorded West Palaearctic E. exarmata.

\section{New information}

The last instar larva and prepupa of $E$. exarmata is illustrated and briefly described. In Germany its host is Fraxinus excelsior.

\section{Keywords}

Eupareophora exarmata, sawfly, larva, prepupa, Rosaceae, ash species, Fraxinus, Germany 


\section{Introduction}

Eupareophora exarmata (Thomson, 1871) is a rarely recorded sawfly species with a wide West Palaearctic range extending from southern Sweden (type locality: Lund; Thomson 1871) to Spain (Taeger et al. 2006) and reaching the Caucasus in the East (Supatashvili et al. 1972). The only other known Eupareophora species is the Nearctic E. parca (Cresson, 1880). While the larva, hosts and biology of $E$. parca are described and discussed by Smith 1969 and Williams 2007, very little such information is available on E. exarmata. During recent years several distinctive sawfly larvae were found at a locality in north-west Germany, associated with ash (Fraxinus excelsior). Although adults were not reared, examination of the morphology of the larvae and a comparison of a mitochondrial DNA sequence from one prepupa with sequences of other Tenthredinidae, indicated beyond reasonable doubt that they belong to $E$. exarmata. We hope that the short, illustrated descriptions of the mature larva and prepupa provided below may lead to increased recording of this sawfly species.

\section{Materials and methods}

\section{Material examined: Eupareophora exarmata}

Germany, Nordrhein-Westfalen, Hagen-Hohenlimburg, 51.32099, N 7.57673 E, 172 m. a.s.I., all records by J. Bücker: 31.5.2009, 2 larvae about 30-50 cm above soil level on trunk of approximately 50 year old Fraxinus excelsior, 24.5.2011, 5 larvae, on same tree but $50-120 \mathrm{~cm}$ above soil level; 2.6.2012, 1 larva on metal fence post. On the first two dates larvae were photographed but not collected. The last larva was collected. It moulted to the prepupal stage within 24 hours of being found. In anology with the observations by Williams 2007 on E. parca, it was probably 5th instar when collected. The cast larval skin was dry-mounted, and the prepupa conserved in ethanol. These specimens are deposited in the Senckenberg Deutsches Entomologisches Institut, Müncheberg.

\section{Molecular methods}

To assess the phylogenetic position of Eupareophora exarmata within Tenthredinidae, full or partial (at least $1119 \mathrm{bp}$ ) cytochrome c oxidase I gene (COI) sequences were sequenced from the prepupa of the putative E. exarmata (GenBank accession KT964163) as well as various other tenthredinids as described previously (Prous et al. 2011; Prous and Heidemaa 2012). Some additional COI sequences representing broad diversity of Tenthredinidae, Cimbicidae, Diprionidae, and Heptamelus, and which were at least 1000 bp long, were downloaded from NCBI nucleotide database (http:// www.ncbi.nlm.nih.gov/nucleotide). The downloaded sequences were published previously by Prous et al. 2011, Boevé et al. 2013, Wei et al. 2015a, Wei et al. 2015b, Malm and Nyman 2014, and Song et al. 2015. Only the downloaded COI sequence of Eupareophora parca was shorter than others (KF528474; 862 bp), because this was the only Eupareophora sequence publicly available. Representatives of Cimbicidae, Diprionidae, 
and Heptamelus were used as an outgroup, as these are the closest relatives of Tenthredinidae (Malm \& Nyman 2015). PhyML (Guindon et al. 2010) was used to estimate a maximum likelihood tree of Tenthredindae $\mathrm{CO}$ sequences. GTR+G model was employed and node support values were evaluated based on 500 bootstrap replicates using PhyML online version (http://www.atgc-montpellier.fr/phyml/). Following the results of Malm and Nyman 2014, Heptamelus was used to root the tree. Newly obtained sequences have been deposited in the GenBank (NCBI) database (accession numbers KT964153KT964167).

\section{Taxon treatment}

\section{Eupareophora exarmata (Thomson, 1871)}

\section{Material}

a. $\quad$ scientificName: Eupareophora exarmata (Thomson, 1871); taxonomicStatus: accepted; kingdom: Animalia; phylum: Arthropoda; class: Insecta; order: Hymenoptera; family: Tenthredinidae; nomenclaturalCode: ICZN; genus: Eupareophora; specificEpithet: exarmata; scientificNameAuthorship: Thomson, 1871; continent: Eurasia; country: Germany; countryCode: DE; stateProvince: Nordrhein-Westfalen; locality: HagenHohenlimburg; decimalLatitude: 51.32099; decimalLongitude: 7.57673; year: 2012; month: 6; day: 2; individualCount: 1; lifeStage: prepupa; preparations: whole animal (ethanol) and larval exuvia; catalogNumber: DEI-GISHym19361; occurrenceStatus: present; disposition: in collection; identifiedBy: Andrew Liston; type: PhysicalObject; language: en; institutionCode: SDEI; basisOfRecord: PreservedSpecimen

\section{Description}

\section{Sequencing results}

Phylogenetic analyses of $1078 \mathrm{bp}$ of $\mathrm{COI}$ sequences showed with strong statistical support (bootstrap proportion 92\%) that the closest relative of the putative Eupareophora exarmata prepupa is the Nearctic E. parca (Fig. 1), from which it nevertheless differs significantly at the sequence level, by $10.8 \%$. The tree is otherwise poorly resolved, because of the limited amount of sequence data used. Closest relatives of the genus Eupareophora on the tree are Cladardis, Monardis, and Periclista, although without statistical support (Fig. 1). A strongly supported clade of the latter three genera was found by Malm and Nyman 2014 using 8 nuclear and one mitochondrial (COI) protein coding genes, suggesting that Eupareophora (which Malm \& Nyman 2015 did not sample) might also belong there. 


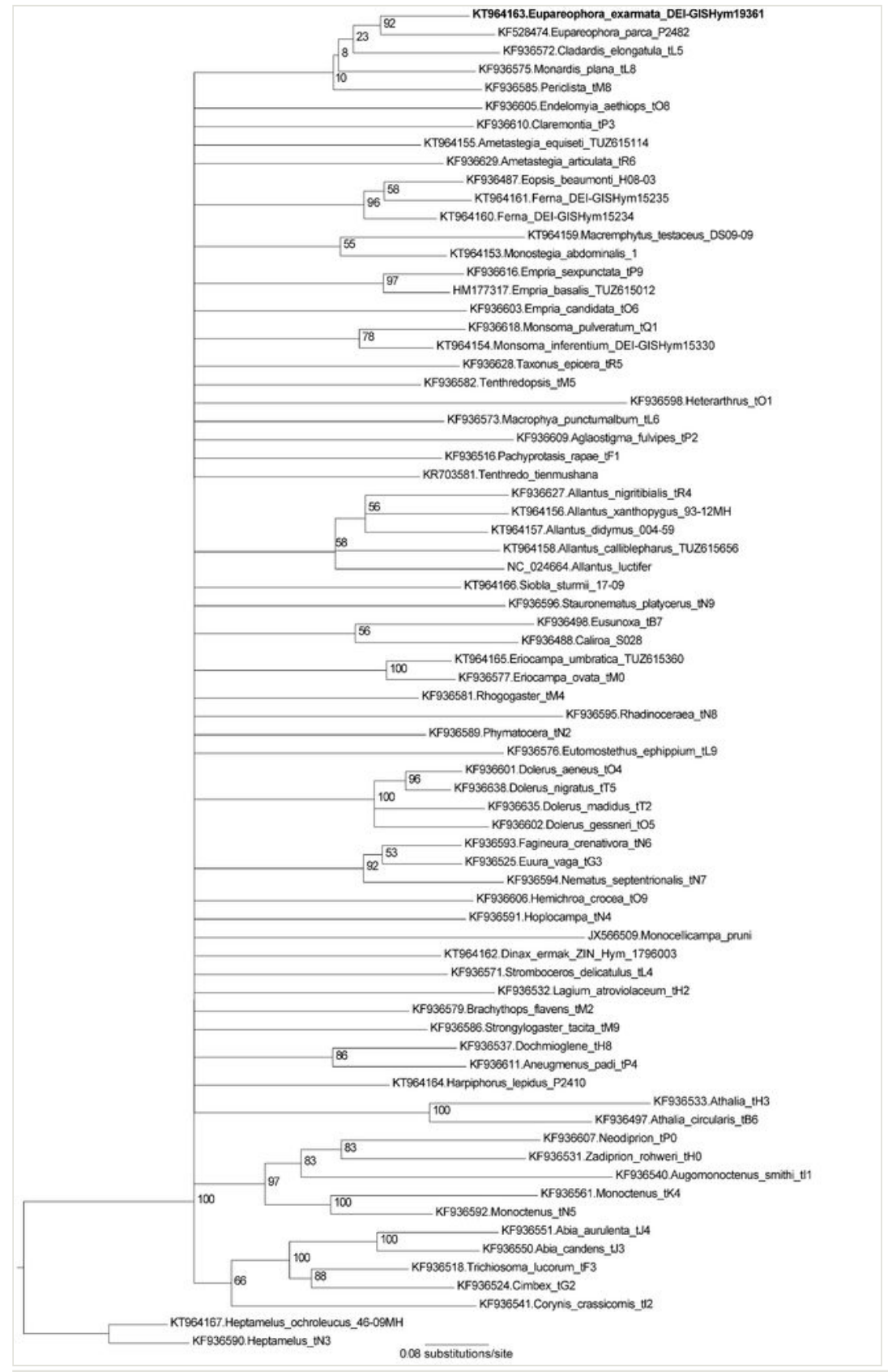

Figure 1.

Maximum likelihood tree of COI (1078 bp) sequences of Tenthredinidae. Numbers at nodes are bootstrap proportions (\%) derived from 500 pseudoreplicates. Nodes receiving bootstrap support less than $50 \%$ have been collapsed, except for those closest to Eupareophora. 


\section{Hosts}

Liston 1995 stated that the hosts of Eupareophora exarmata are Rosa species (Rosaceae) and that the larvae bore in shoots. Although not cited by Liston, this statement was based on a record by Reichert 1933: "mit Larven von Ardis brunniventris eingetragene Rosenzweige ergaben 13.2.18. im geheizten Zimmer 1 \#w, det Enslin". In view of the morphological similarity of adult $M$. plana (whose hosts are Rosa spp.: Scheibelreiter 1973) and E. exarmata, it seems likely that Enslin misidentified the specimen. Zhelochovtsev [Zhelohovcev] 1988) mentioned under E. exarmata simply "on ash" [translated] (Fraxinus sp., Oleaceae). Probably this information is based on original observations made by Supatashvili et al. 1972 al. (1972) in Georgia, who reared adults from larvae. Adults were examined by Zhelochovtsev and determined as E. exarmata. The larva is very briefly described by Supatashvili et al. 1972 [translated]: "Larva grey coloured, body covered with awl-shaped processes". These authors also record "ash" as the host, but do not mention which Fraxinus species was involved. Apart from Fraxinus excelsior L., some other ash species occur in Georgia, such as $F$. angustifolia Vahl subsp. oxycarpa (M. Bieb. ex Willd.) Franco \& Rocha Afonso (USDA 2012). The recent German records indicate that $F$. excelsior $L$. is a host. As far as we are aware, the publication by Supatashvili et al. 1972 is unique in referring to $E$. exarmata as a pest. Their observations were made in stands of planted ash. It is noteworthy that the occasional reports of defoliation caused by $E$. parca in North America involve "planted ash species [..] in urban settings" (Williams 2007), although D. R. Smith (personal communication) states that it is also fairly common throughout the eastern deciduous forests.

\section{Description of mature larva (Figs 2, 3, 4).}

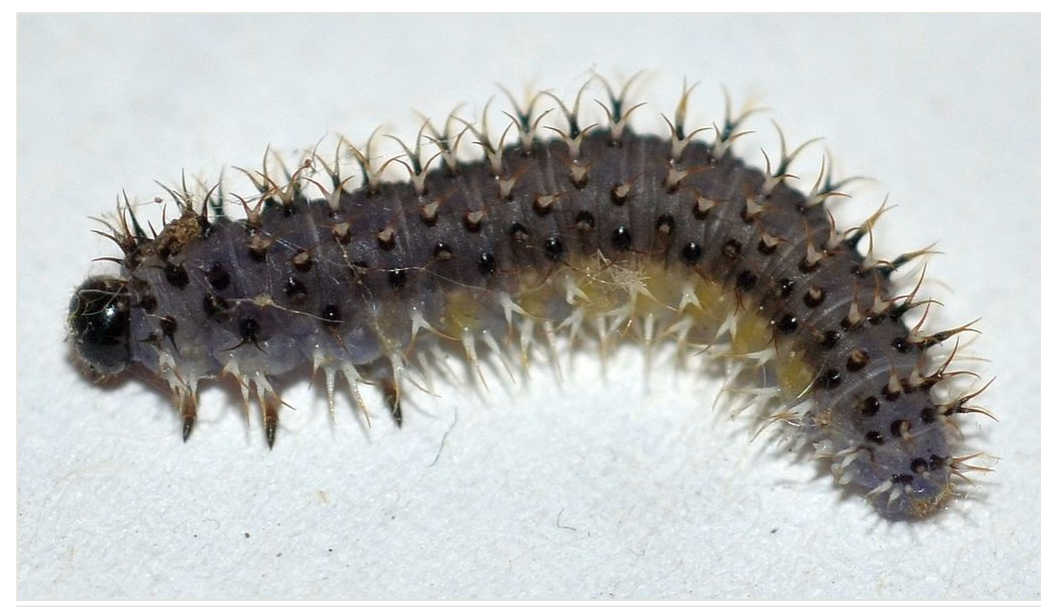

Figure 2.

Eupareophora exarmata, larva, last feeding instar; Germany, Hagen-Hohenlimburg. Photos: J. Bücker. 


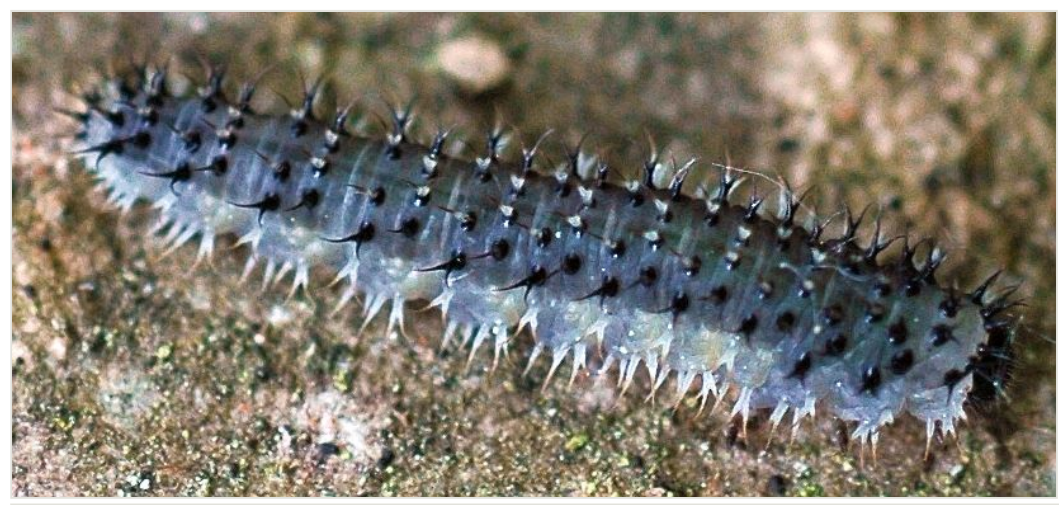

Figure 3.

Eupareophora exarmata, larva, last feeding instar.

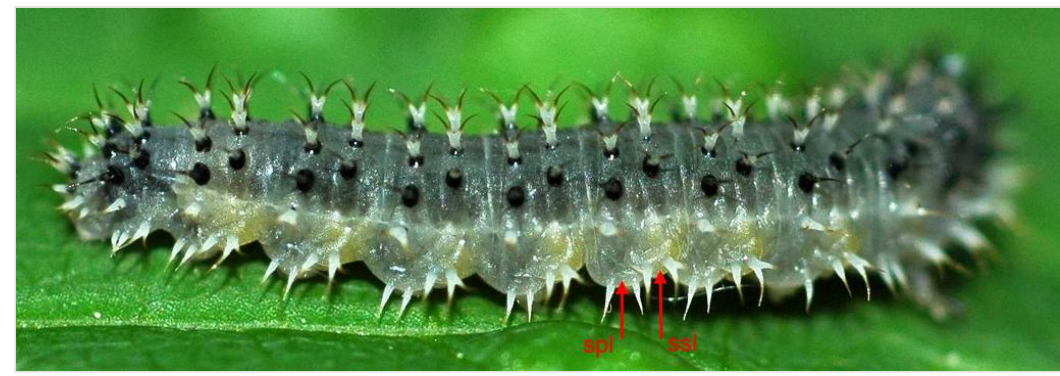

Figure 4.

Eupareophora exarmata, larva, last feeding instar; spl=surpedal lobe, ssl=subspiracular lobe.

Terminology follows Viitasaari 2002, with notation of annulets of abdominal segments according to Vikberg and Nuorteva 1997, i.e. annulet 3 bears the spiracle.

Length: approximately $15 \mathrm{~mm}$.

Head completely black except for pale mouthparts. Ground colour of trunk above spiracular line grey; whitish below this, with yellow tinge on abdominal segments 1-8. Cuticular processes (hereafter: spines) above spiracles located on more or less black glandubae. Above spiracles, on thorax, most spines entirely black; on abdomen all supraspiracular spines blackish above fork, whitish below this; the outermost of each dorsal pair of spines darker. All subspiracular spines paler than more dorsal ones; apically at most pale brown, and if located on glandubae, then these also completely pale.

Antenna with 5 articles. Clypeus with 2 setae. Thoracic leg with 5 articles. The 4 most dorsal and anterior spines on thorax are trifid. Prolegs on abdominal segments 2-8 and 10. Abdominal segments 1-9 with 5 dorsal annulets. Annulet 3 with 2 supraspiracular bifid spines. Annulet 5 with 3 bifid spines: 2 supraspiracular and 1 on spiracular line. 
Abdominal segment 10 without spine on midline. Subspiracular lobe with two spines; anterior one bifid, other simple. Suprapedal lobe with two simple spines.

Description of prepupa (Fig. 5).

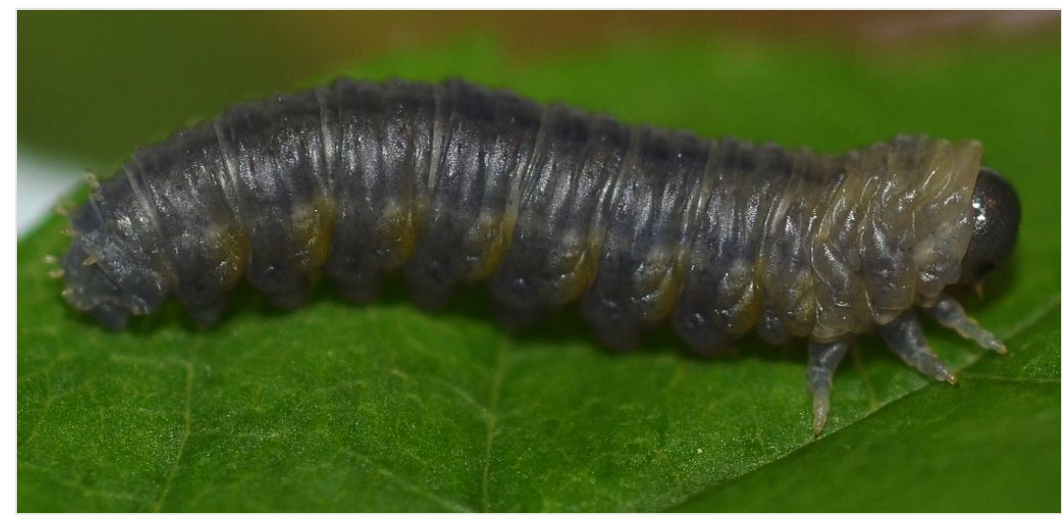

Figure 5.

Eupareophora exarmata, Germany, Hagen-Hohenlimburg; prepupa. Photo: J. Bücker.

Length: approximately $13 \mathrm{~mm}$.

Head grey above; yellowish on and around mouthparts. Thorax yellow-white. Abdomen largely grey, with yellow patches on and below spiracular line, and yellowish prolegs.

Spines absent, except on abdominal segments 9 and 10, where they are replaced by unbranched, peg-shaped structures. Prothorax dorsally and anteriorly more strongly produced than in the feeding larva, giving it a hooded appearance.

\section{Identification}

Other spiny West Palaearctic Blennocampinae larvae belong to the genera Monardis, Periclista, Pareophora, Monophadnoides and Claremontia. Larvae of all of these, none of which feeds on Fraxinus, have a mainly pale green or yellowish body and are thus easily distinguished from the predominantly grey larva of E. exarmata. Smith 1969 stated that the larva of Eupareophora parca has two bifurcate spines on the subspiracular lobe, and can therefore be distinguished from those of Periclista species in which the anterior of these two spines is bifurcate and the posterior one simple. The larva of E. exarmata in this respect (Fig. 4) is however like Periclista, not E. parca. The coloration of the mature larva of $E$. parca (illustrated by Williams 2007) and $E$. exarmata (Figs 2, 3, 4) is similar, although the latter is apparently darker. According to Williams 2007 (fig. 10B), the caudal abdominal terga of the E. parca prepupa entirely lack large cuticular processes, whereas the prepupa of $E$. exarmata clearly possesses some (Fig. 5). 


\section{Behaviour}

All adult collection records and observations on larvae (here, and by Supatashvili et al. 1972 , suggest that $E$. exarmata is univoltine, flying soon after bud-break in spring, with larvae developing, according to local climate, between the end of April and start of June. The behaviour of the feeding larvae, although only briefly described by Supatashvili et al. 1972 seems to resemble quite closely that of the Nearctic E. parca as described by Williams 2007.

At Hagen-Hohenlimburg only mature larvae of $E$. exarmata were found, apparently when they crawled down the trunk of the host in order to reach a spot in which to complete their development. Williams 2007 recovered eight prepupae of $E$. parca from the soil litter layer, and 2 from branches of the host. Further observations are therefore needed to establish whether $E$. exarmata always leaves its host before moulting to a prepupa. According to Supatashvili et al. 1972, the mature larvae form cells in the bark of Fraxinus, in which they overwinter. A further apparent peculiarity noted by these authors, is that the freshly moulted larvae lack spines, but that these re-appear within a day. Neither of these phenomena was observed by Williams 2007 in the Nearctic $E$. parca, who found that the rather flimsy cocoon was usually constructed in the upper layers of the soil.

\section{References}

- $\quad$ Boevé J, Blank SM, Meijer G, Nyman T (2013) Invertebrate and avian predators as drivers of chemical defensive strategies in tenthredinid sawflies. BMC Evolutionary Biology 13 (1): 198. DOI: 10.1186/1471-2148-13-198

- $\quad$ Guindon S, Dufayard JF, Lefort V, Anisimova M, Hordijk W, Gascuel O (2010) New Algorithms and Methods to Estimate Maximum-Likelihood Phylogenies: Assessing the Performance of PhyML 3.0. Systematic Biology 59 (3): 307-321. DOI: 10.1093/sysbio/ syg010

- $\quad$ Liston AD (1995) Compendium of European Sawflies. List of species, modern nomenclature, distribution, foodplants, identification literature. Chalastos Forestry, Gottfrieding, 190 pp. [In English].

- Malm T, Nyman T (2014) Phylogeny of the symphytan grade of Hymenoptera: new pieces into the old jigsaw(fly) puzzle. Cladistics 31 (1): 1-17. DOI: $10.1111 /$ cla.12069

- $\quad$ Prous M, Heidemaa M (2012) Empria formosana sp. n. from Taiwan with notes on $E$. wui species group (Hymenoptera, Tenthredinidae). Deutsche Entomologische Zeitschrift 59: 249-257. DOI: 10.1002/mmnd.201200021

- $\quad$ Prous M, Heidemaa M, Soon V (2011) Empria longicornis species group: taxonomic revision with notes on phylogeny and ecology (Hymenoptera, Tenthredinidae). Zootaxa 2756: 1-39.

- $\quad$ Reichert A (1933) Die Tenthredinoidea von Leipzig und Umgegend. Sitzungsberichte der Naturforschenden Gesellschaft zu Leipzig 56-59: 37-74.

- $\quad$ Scheibelreiter GK (1973) Die Tenthrediniden der Rose (Rosa spec.). Zeitschrift für angewandte Entomologie 72 (3): 225-259. 
- Smith DR (1969) Nearctic Sawflies. I. Blennocampinae: Adults and larvae (Hymenoptera: Tenthredinidae). Technical Bulletin. 1397. U.S. Department of Agriculture, Washington DC, $176 \mathrm{pp}$.

- $\quad$ Song S, Wang Z, Lic Y, Wei S, Chen X (2015) The mitochondrial genome of Tenthredo tienmushana (Takeuchi) and a related phylogenetic analysis of the sawflies (Insecta: Hymenoptera). Mitochondrial DNA in press. DOI: $10.3109 / 19401736.2015 .1053129$

- Supatashvili SM, Shalibashvili GK, Supatashvili AS (1972) [New representatives of the insect pest fauna of forest and park plantations in Georgia.]. Bulletin of the Academy of Sciences of the Georgian SSR 68 (1): 217-220. [In Russian].

- $\quad$ Taeger A, Blank SM, Liston AD (2006) European Sawflies (Hymenoptera: Symphyta) A Species Checklist for the Countries. In: Blank SM, Schmidt S, Taeger A (Eds) Recent Sawfly Research: Synthesis and Prospects. Goecke \& Evers, Keltern, 704 pp.

- Thomson CG (1871) Hymenoptera Scandinaviae (Tenthredo et Sirex Lin.). H. Olsson, Lund, 342 pp. [In Swedish and Latin].

- $\quad$ USDA ANGRP (2012) Germplasm Resources Information Network - (GRIN). http:// www.ars-grin.gov/cgi-bin/npgs/html/taxon.pl?315869. Accession date: 2012925.

- Viitasaari M (2002) The Suborder Symphyta of the Hymenoptera. In: Viitasaari M (Ed.) Sawflies (Hymenoptera, Symphyta) I. A review of the suborder, the Western Palaearctic taxa of Xyeloidea and Pamphilioidea. Tremex, Helsinki, $516 \mathrm{pp}$.

- Vikberg V, Nuorteva M (1997) On the rearing of Nesoselandria morio (Fabricius) and Birka cinereipes (Klug) (Hymenoptera, Tenthredinidae), with descriptions of their larvae. Entomologica Fennica 8 (1): 27-38.

- Wei S, Niu F, Du B (2015a) Rearrangement of trnQ-trnM in the mitochondrial genome of Allantus luctifer (Smith) (Hymenoptera: Tenthredinidae). Mitochondrial DNA in press: 0-0. DOI: 10.3109/19401736.2013.819501

- Wei S, Wu Q, Liu W (2015b) Sequencing and characterization of the Monocellicampa pruni (Hymenoptera: Tenthredinidae) mitochondrial genome. Mitochondrial DNA 26: 157-158. DOI: 10.3109/19401736.2013.819501

- Williams DJ (2007) Biology of the spiny ash sawfly, Eupareophora parca (Hymenoptera: Tenthredinidae: Blennocampinae), in Edmonton, Alberta. Canadian Entomologist 139: 269-277. DOI: 10.4039/n06-026

- Zhelochovtsev [Zhelohovcev] AN (1988) [27. Order Hymenoptera - Wasps Suborder Symphyta (Chalastogastra) - Sawflies and woodwasps.]. In: Zhelohovcev AN, Tobias VI, Kozlov MA (Eds) Keys to the fauna of the USSR, edited by the Zoological Institute of the Academy of Sciences of the USSR. 158. Nauka, Leningrad, 268 pp. [In Russian]. 